\title{
The Contribution of Resident Vascular Stem Cells to Arterial Pathology
}

\author{
Augusto Orlandi \\ Anatomic Pathology Institute, Department of Biomedicine and Prevention, \\ Tor Vergata University of Rome, Rome, Italy
}

Intimal accumulation of smooth muscle cells contributes to the development and progression of atherosclerotic lesions and restenosis following endovascular procedures. Arterial smooth muscle cells display heterogeneous phenotypes in both physiological and pathological conditions. In response to injury, dedifferentiated or synthetic smooth muscle cells proliferate and migrate from the tunica media into the intima. As a consequence, smooth muscle cells in vascular lesions show a prevalent dedifferentiated phenotype compared to the contractile appearance of normal media smooth muscle cells. The discovery of abundant stem antigen-expressing cells in vascular lesions also rarely detected in the tunica media of normal adult vessels stimulated a great scientific debate concerning the possibility that proliferating vascular wall-resident stem cells accumulate into the neointima and contribute to the progression of lesions. Although several experimental studies support this hypothesis, others researchers suggest a positive effect of stem cells on plaque stabilization. So, the real contribute of vascular wall-resident stem cells to pathological vascular remodelling needs further investigation. This review will examine the evidence and the contribution of vascular wall-resident stem cells to arterial pathobiology, in order to address future investigations as potential therapeutic target to prevent the progression of vascular diseases.

Keywords: Arterial wall, Intimal thickening, Smooth muscle cells, Resident stem cells, Smooth muscle cell heterogeneity

\section{Introduction}

Accumulation of smooth muscle cells (SMCs) in the tunica intima plays a crucial role in the pathogenesis of vascular lesions, including atherosclerosis and restenosis following angioplasty or stenting procedures $(1,2)$. In the classical pathogenetic hypothesis of atherosclerosis, follow-

Accepted for publication April 8, 2015, Published online May 30, 2015

Correspondence to Augusto Orlandi

Anatomic Pathology Institute, Department of Biomedicine and Prevention, Tor Vergata University of Rome - PTV, Via Montpellier, 00133 Rome, Italy

Tel: +39.06.20903960, Fax: +39.06.20902209

E-mail: orlandi@uniroma2.it

(a) This is an open-access article distributed under the terms of the Creative Commons Attribution Non-Commercial License (http://creativecommons.org/ licenses/by-nc/4.0/), which permits unrestricted non-commercial use, distribution, and reproduction in any medium, provided the original work is properly cited. ing injury growth factors and proteolytic agents induce SMC proliferation and migration from the tunica media into the intima (3). During this process, SMCs switch from a "contractile" to a "synthetic" phenotype, characterized from reduced expression of contractile proteins and enhanced response to growth and chemotactic factors (4). In atherosclerosis, SMC accumulation in the fibrous cap is monoclonal or oligoclonal $(5,6)$, implying that only a small number of medial SMCs proliferate in response to injury. This finding suggests the existence of a resident arterial stem cell subpopulation contributing to arterial healing in response to injury. Studies in human transplantation arteriopathy and primary atherosclerotic lesions showed that recruited bone marrow or host-derived circulating precursors are present in the lesions (6-8). Successively, other studies refused this hypothesis $(9,10)$, suggesting that SMCs in vascular lesions are mainly derived from the host parietal response. In parallel, the pres- 
ence of cells expressing stem cell antigens have been identified in the normal arterial wall $(11,12)$, supporting a potential role of adult vascular wall-resident stem cells (VRSCs) in vascular pathobiology. In this review, the characteristics and the potential contribution of VRSCs to the development of great vessel lesions are discussed.

\section{Adult arterial vascular smooth muscle cells are phenotypically heterogeneous}

Classically, SMCs within the normal tunica media of the adult vascular wall are heterogeneous, and a "contractile" and "synthetic" phenotype identified $(13,14)$. SMCs dis-
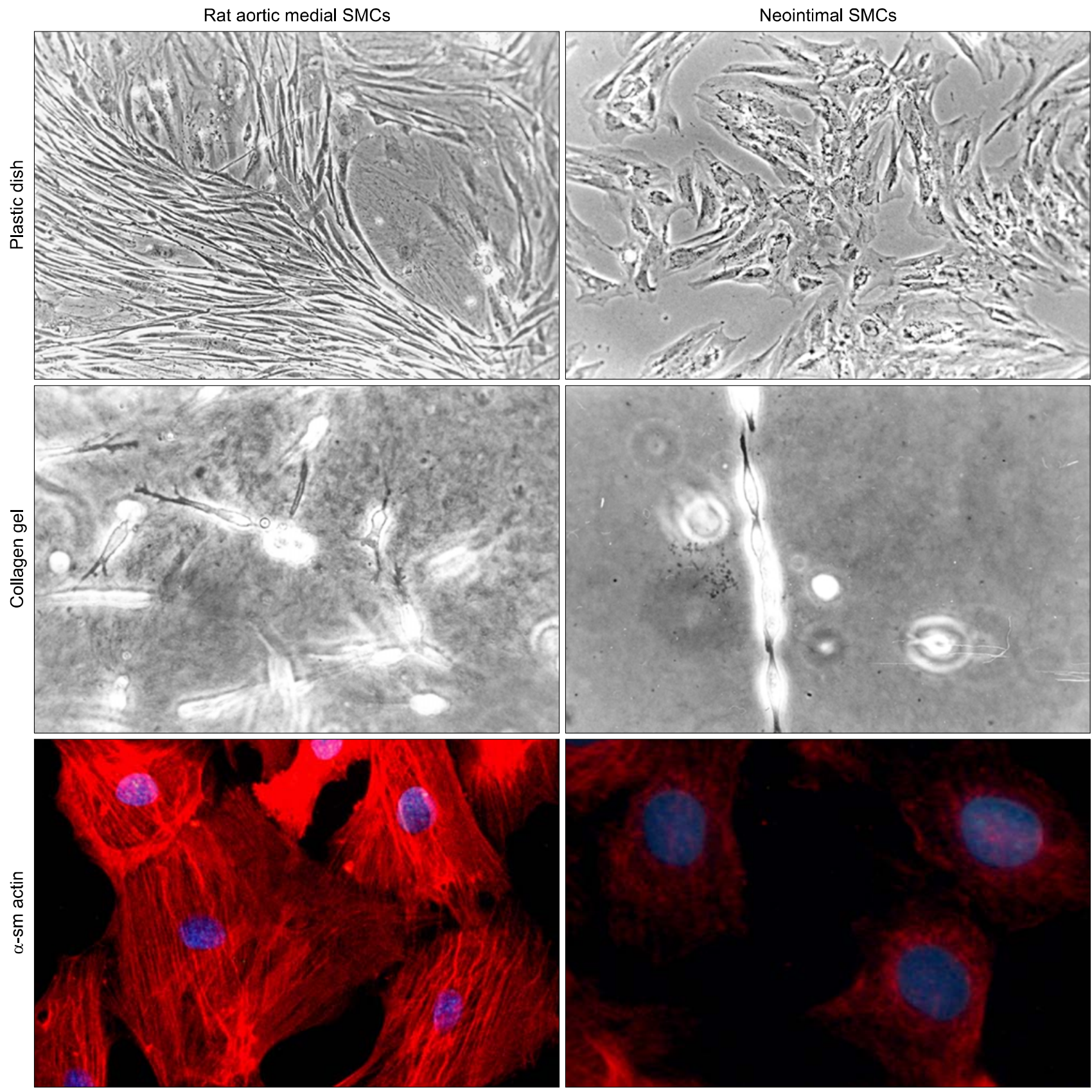

Fig. 1. phenotypic heterogeneity of adult vascular smooth muscle cells. Rat aortic normal media SMCs (left column) display with the classical "hill-and-valley" confluent grow pattern when cultured in plastic dishes, a more dendritic shape with a marked extracellular matrix remodelling when cultured in collagen gel and display abundant $\alpha$-smooth muscle actin ( $\alpha$-sm actin)-positive stress fibers in immunofluorescence (rhodamine, bottom). In contrast, neointimal VSMCs obtained fifteen days after ballooning (right column) display a monolayered and epithelioid appearance (top), grow in Indian files with bipolar conjunctions in collagen gel and contain very low amount of $\alpha$-smooth muscle actin (bottom). 
playing a synthetic phenotype can be identified more frequently in pathologic arteries and have been characterized in vitro (Fig. 1). Synthetic SMCs obtained from intimal

Table 1. Stem antigens of adult vascular wall-resident stem cells

\begin{tabular}{cl}
\hline Stem antigen/synonim & \multicolumn{1}{c}{ Localization/type } \\
\hline CD133 & Transmembrane glycoprotein \\
CD34 & Transmembrane sialomucin protein \\
Flt-1 (VEGFR-1) & Transmembrane kinase receptor \\
KDR (VEGFR-2) & Transmembrane kinase receptor \\
c-kit (CD117) & Transmembrane tyrosine-protein kinase \\
& receptor \\
CD45 & Protein tyrosine phosphatase \\
CD14 & Cytoplasmic endotoxin receptor \\
sca-1 & Transmembrane class III tyrosine kinase \\
& receptor \\
Notch-1 & Transmembrane regulatory receptor \\
\hline
\end{tabular}

aortic tissue fifteen days after balloon injury displayed a monolayered epithelioid phenotype, with a cobblestone morphology, markedly different from the "hill-and-valley" growth pattern typical of normal medial VSMCs $(14,15)$. Moreover, neointimal cells express low amount of myocitic markers and differences are maintained in clonal expansion (14-16). It is worth of noting contractile and synthetic phenotypes are not permanent and can partially revert after stimulation with growth factors and extracellular matrix molecules (17-19). Phenotypically-regulated activation of proteins and receptors regulates differences in terms of proliferation and survival, being proliferating aortic neointimal VSMCs more sensitive to apoptosis (20). likely linked to a phenotype-regulated different NF- $\mathrm{KB}$ activity $(21,22)$. Phenotype-dependent expression of integrins in vascular SMC regulates morphology, motility and gene expression in collagen matrix (Fig. 1; 18). A hy-
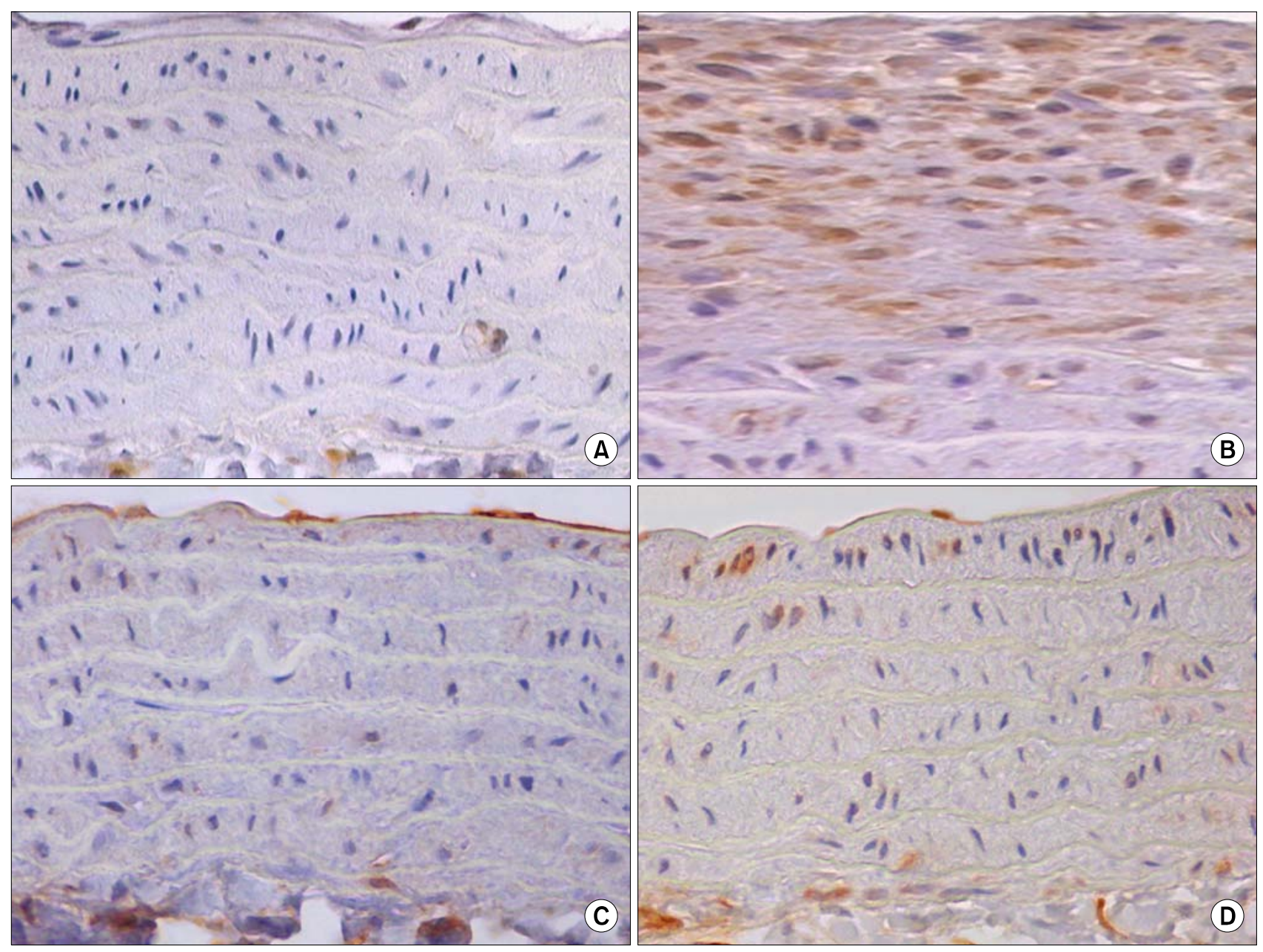

Fig. 2. Stem cell expression in rat aorta after injury and with aging. Serial immunostainings reveal (A) very rare cell are c-kit ${ }^{+}$positive in normal 2 month-old rat aorta. (B) fifteen days after ballon injury, the majority of intimal and some of medial SMCs are c-kit ${ }^{+}$positive. (C) Very rare SMCs are flt- $1^{+}$in normal 2 month-old rat aorta, but (D) the number of flt- ${ }^{+}$cells increases in 24 -month old rat aorta. 
pothesis to explain SMC heterogeneity in adult vessels is a different embryologic origin during vasculogenesis (23). In the chick embryo aorta, spindle-shaped and epithelioid phenotypes responding differently to TGF- $\beta$ were isolated from distinct mesoderm and neural crest-derived regions (24). It is likely that the capacity of a different response to damage can be retained from SMCs during the adult life.

\section{The existence of adult vascular wall-resident stem cells}

Mesenchymal smooth muscle progenitors have been identified in the bone marrow, in the blood as circulating progenitors and in extravascular sites (25-27). Identification of these progenitor cells was mainly based on the finding of stem antigens shared from a SMC subpopulation in the normal arterial wall and/or in vascular lesions. Recent studies identified and characterised a small population of resident SMCs in the wall of great vessels of healthy adult mice expressing scal and low amounts of c-kit and CD34, absent in the adventitia (28). These putative VRSCs differ from bone marrow-derived smooth muscle progenitors or form those isolated from skeletal muscle, since they lack the ability to differentiate into lymphoid or myeloid lineages (29). A clonal subpopulation of vascular cells from the bovine aortic tunica media was phenotypically similar $\left(\mathrm{CD} 29^{+}, \mathrm{CD}_{4} 4^{+}, \mathrm{CD} 14^{-}, \mathrm{CD} 45^{-}\right)$to bone marrow-derived mesenchymal stem cells (30). Progenitor cells named "mesoangioblasts" isolated from explants of murine dorsal aorta display differentiative potential into various mesenchymal cell types other than myocitic cells in vitro and express both myogenic and endothelial markers $(31,32)$. The expression of main stem markers of adult VRSCs are listed in Table 1. Immunohistochemical investigation revealed c-kit ${ }^{+}$and $\mathrm{CD} 133^{+}$cells in human atherosclerotic plaques and restenosis lesions and in rat aortic post-injury neointima, whereas SMCs in the tunica media of primary atherosclerotic plaques and normal arteries were c-kit- (11, 33). Progenitor cells expressing sca-1, CD34, KDR and c-kit were detected within human plaques and the adventitia (11). Most of the knowledge concerning stem phenotype derives from studies of animal models of vascular injury. VEGFR-1 or flt- $1^{+}$and c-kit ${ }^{+}$SMCs are extremely rare in normal rat aorta, whereas their number dramatically increases fifteen days after injury (Fig. 2), with many of intimal cells co-expressing both $\alpha$-smooth actin and flt-1 or c-kit (12). After sixty days, after complete re-endothelialization stem marker-expressing intimal cells almost disappeared and $\alpha$-smooth actin expression restored (12). Double immunostaining experiments revealed that $\mathrm{flt}^{-} \mathrm{1}^{+}$

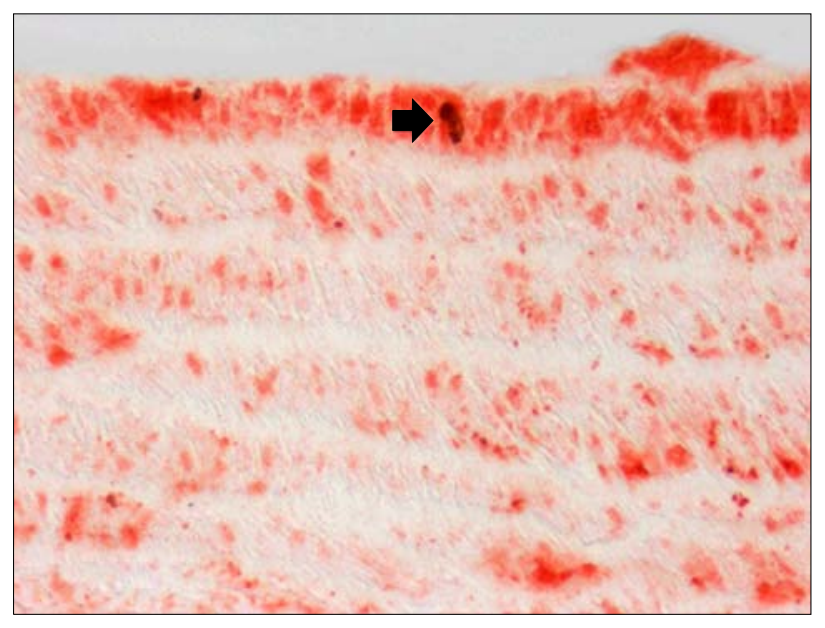

Fig. 3. flt-1 expression and smooth muscle cell proliferation. Double immunostaining reveals that flt- 1 expression (red) characterizes rat aortic bromodeoxyurinine + proliferating SMC (arrow, black) in the tunica media three days after ballooning.

medial are also positive for anti-bromodeoxyuridine (Fig. 3) or apoptotic TUNEL staining, confirming the preferential involvement of flt- $1^{+}$cells in proliferative and apoptotic behaviour $(22,34,35)$. Similarly, many intimal cells of mice carotid arteries express Hedgehog-induced Notch 1 early after injury (36).

\section{The adventitial origin of vascular-wall resident stem cells}

Although recent studies supported the hypothesis that the majority of SMCs in vascular lesions originates from the vessel wall, an open question remains the layer of origin of VRSCs. After early reports documenting that activation of adventitial fibroblasts precedes post-damage experimental neointimal proliferation (37), increasing evidence accumulated supporting the involvement of adventitial vascular progenitor cells in the development of arteriosclerosis, including transplant arteriosclerosis, angioplasty-induced restenosis, vein graft atherosclerosis, and spontaneous atherosclerosis. The adventitia of the arterial wall contains progenitor cells, which can differentiate into vascular SMCs. In apoE-deficient mice These progenitor cells were able to migrate from the adventitia into the intima, where they accumulate to contribute to atherosclerotic lesions of vein grafts (38). Hu et al. (2004) showed documented aortic adventitial cells in apoE-deficient mice expressing sca-1 and c-kit stem cell markers; moreover, ex vivo PDGFB-stimulated adventitial stem cell-expressing cells displayed a myocytic phenotype with the expression multiple smooth muscle markers (39). Lineage tracking 
with bone marrow transplantation from ROSA 26 LacZ gene-expressing transgenic mice documented that adventitia-derived smooth muscle precursors migrate to the neointima in a vein graft atherosclerosis model, with no evidence of a bone marrow origin (39). The same Authors suggested that the extent of injury is crucial to regulate mobilization of adventitial progenitor cell and their contribution to vascular lesions. Several issues remain unresolved as to the physiologic relevance of adventitial progenitor cells, and if these cells are also documented in human lesions. Adult vascular adventitial tissue contains mature adipose tissue. Recently, an adipose-derived stem population has been well characterized (40-45). Adipose derived stem cells are capable to regenerate de novo mesenchymal tissue and are widely used foR their pluripotential regenerative potential (46-52). In most of these studies, vascular transdifferentiation is reported as a crucial event to explain clinical efficacy of adipose-derived stem cells to ameliorate grafting and tissue regeneration. It is interesting to note that, differently from adipose-derived stem cells, bone marrow-derived circulating progenitor cells do not transdifferentiate into adipocytes in vivo and play little, if any, role in expanding the number of resident adipocytes during tissue growth (53). These findings strongly support that de novo vessel formation and/or vascular remodelling involve transdifferentiation of adventitial adipose-derived stem cells. Conversely, in long-term cultures adipose tissue-derived perivascular cells retained myogenicity and mesenchymal stem cell markers expression, similar to native, non-cultured perivascular cells (53). The vasculogenesis-promoting potential of adventitial adipose-derived stem cells depends on interaction with resident endothelial cells and involving contact and bi-directional interaction, resulting in modulated secretion of cytokines and extracellular matrix molecules, so leading to vascular remodeling (54). Cellular communication occurring between adventitial adipose-derived stem cells and endothelial precursor cells and triggered by cell-cell contact is partially mediated by secreted VEGF, but this effect is not observed by using HUVECs, suggesting that adipose-derived stem cells are unique in this sense (55). Being adventitial precursors a potential source of SMCs, the modulation of the contribution of these progenitor cells is a potential tool to counteract pathological vascular remodeling by cellular, genetic, and tissue engineering approaches.

\section{The pericyte-like phenotype of adult vascular wall-resident stem cells}

Blood vessel walls harbor a reserve of progenitor cells that may be integral to the origin of non-vascular tissues as other related adult stem cells (56). Recently, resident pericyte-like cells from the adventitia have been hypothesized to contribute to restenosis. Rare NG2, PDGFR $\beta$ and CD146-expressing cells identified in the adventitia of uninjured mouse femoral arteries in response to injury increased in number and expressed a SMC-like phenotype (31). Bone marrow transplantation and ex vivo artery culture strongly supported that pericyte-like progenitor cells are not bone marrow-derived, but originated from the adventitia after proliferation of resident perivascular pericyte-like cells (32). Cells with progenitor pericyte-like properties have been also isolated from the tunica media of adult rat aortas and are capable to generate spheroidal colonies in suspension and, when serum-cultured, retain CD34 negativity and express de novo SMC markers (32). The relationship between this population of resident adventitial pericyte-like cells, reparative myofibroblasts, normal media SMCs and other progenitor populations during pathological vascular remodelling is still matter of debate and need further investigation.

\section{The contribution of adult vascular wall-resident stem cells to vascular lesion progression}

The discovery of the existence of VRSCs has challenged the classical pathogenetic model of tunica media as unique source of SMCs contributing to vascular lesions (1, 2). Atherosclerosis is a chronic inflammatory disease, in which risk factors result in dysfunction and damage to the arterial endothelium and slow progression, characterized from intimal accumulation of SMCs in a fibromuscular cap covering a cholesterol-rich necrotic core (1). Both SMCs and monocyte-macrophages proliferate, accumulate and undergo apoptosis into the neointima $(1,2,34,35)$. In restenotic lesions, after acute injury, rapid proliferation and subsequent accumulation of SMCs from the tunica media into the intima results in rapid lumen occlusion. In these lesions, SMC progenitors have been identified by the expression of bone marrow or progenitor cell markers in vivo. Green florescent bone marrow transplantation in mice revealed that bone marrow-derived cells contribute up to $60 \%$ of SMCs in the post-injury neointima (7). Other studies report that donor-derived cells represent up to $10 \%$ of SMCs within atherosclerotic lesions in humans receiving sex-mismatched bone marrow transplantation (8). The major limit to these investigations was the method to estimate stem marker expression in lesional SMCs and accuracy of co-localisation of two markers, being confocal microscopy rarely performed. When accurate techni- 
ques were applied, even in transplant arteriopathy studies, neointimal SMCs appeared to originate mainly from the recipient aortic wall $(6,9,10)$. Moreover, other studies report that expression of stem markers is present only in early post-injury lesions, questioning about the transient nature of stem phenotype and the survival of these cells (22). Moreover, many studies employed $\alpha$-smooth muscle actin as myocitic marker, but the latter is generally down-regulated in SMCs of vascular lesions (13), but strongly expressed in myofibroblast reparative cells (16). Consequently, those recent studies strongly support the hypothesis that the majority of SMCs in advanced atherosclerotic lesions and healing after plaque rupture originates from the vessel wall. Nevertheless, enhanced adventitial-derived progenitor cell recruitment and increased neointima formation has been seen after growth factor stimulation in animal models of vascular injury $(12,37$, 38), so favoring vascular lesion progression. More recently, it has been reported that smooth muscle progenitor cell enrichment reduces the progression of early but not advanced atherosclerotic lesions plaques in mouse aortas, suggesting a favourable effect on plaque stabilization (57). These findings support a beneficial role of smooth muscle progenitor cells in suppressing atherosclerosis and its clinical sequelae, but still their parietal or extraparietal origin remain under investigation (58). More accurate studies demonstrating whether VRSCs either protect or promote vessel from pathological remodelling are needed, in order to promote cell-based or pharmacological approaches aimed to prevent vascular diseases (59).

\section{Aging and vascular stem cell marker expression}

Accumulation of vascular smooth muscle cells in the tunica intima plays a major role in the pathogenesis of atherosclerosis. Aging represents a risk factor for the development of vascular lesions (60-63) and the prevalence of atherosclerotic lesions in aged subject must be considered in therapeutic and experimental approaches $(19,64)$. Beside proliferation and differentiation, intrinsic aging enhances stem antigen expression in aortic SMCs (65) and, in parallel, susceptibility to atherosclerosis (60). Atherosclerotic lesions and also macroscopically normal human and rat aortas show an increased number of VEGFR- ${ }^{+}$, c-kit ${ }^{+}$and sortilin ${ }^{+}$cells in the intimal thickening $(65,66)$. Both circulating and resident progenitor cells have been evocated to contribute to the response of the adult arterial wall to damage during atherogenetic process and aging (58). Inflammatory cell recruitment induces VEGFR-1-mediated physiological and pathological angiogenesis that favors the increase of vessel lumen increase and its stabilization and counteracts pathological angiogenesis stimulated from PlGF-mutated variants that not bind VEGFR-1 $(67,68)$. These findings suggest that with aging stem cells with a synthetic VEGFR- ${ }^{+}$myocitic phenotype prevail and contribute to aortic myointimal thickening and to vascular angiogenetic/arteriogenetic and healing processes $(69,70)$. If this population derives from perpetual proliferation of VRSCs or phenotypic conversion of previously differentiated SMCs is still object of debate.

\section{Conclusions}

SMCs within the normal tunica media of the adult vascular wall are heterogeneous, and prevalence of a "synthetic" phenotype is found in atherosclerotic and restenotic lesions. Starting from SMC heterogeneity, a considerable accumulating evidence suggests the presence of a small population of VRSCs in different layers of the normal adult arterial wall, and its potential contribute to the homeostasis of post-natal arterial wall but also to pathological remodelling. Progenitor cell mobilisation may be tracked using genetic markers or co-localisation of stem and myocitic markers, but still variability of results is encountered according to the different experimental procedures and techniques. Further accurate studies are needed to define the positive or negative role of VRSCs in arterial pathobiology and to identify if the selective control of VRSC intraparietal mobilization may represent an attractive therapeutic opportunity.

\section{Acknowledgments}

The paper was partially supported from a 2013 grant from Transplantation Agency of Lazio, Italy.

\section{Potential conflict of interest}

The authors have no conflicting financial interest.

\section{References}

1. Ross R, Glomset JA. The pathogenesis of atherosclerosis. Part 1. New Eng J Med 1976;295:369-377

2. Ross R, Glomset J. The pathogenesis of atherosclerosis (second of two parts). New Eng J Med 1976;295:420-425

3. Clowes AW, Reidy MA, Clowes MM. Kinetics of cellular proliferation after arterial injury. I. Smooth muscle growth in the absence of endothelium. Lab Invest 1983;49:327-333

4. Gabbiani G. The cytoskeleton of rat aortic smooth muscle cells. Normal conditions, experimental intimal thickening, and tissue culture. Ann N Y Acad Sci 1986;488:196-198 
5. Benditt EP, Benditt JM. Evidence for a monoclonal origin of human atherosclerotic plaques. Proc Natl Acad Sci U S A $1973 ; 70: 1753-1756$

6. Hu Y, Davison F, Ludewig B, Erdel M, Mayr M, Url M, Dietrich H, Xu Q. Smooth muscle cells in transplant atherosclerotic lesions are originated from recipients, but not bone marrow progenitor cells. Circulation 2002;106:1834-1839

7. Sata M, Saiura A, Kunisato A, Tojo A, Okada S, Tokuhisa T, Hirai H, Makuuchi M, Hirata Y, Nagai R. Hematopoietic stem cells differentiate into vascular cells that participate in the pathogenesis of atherosclerosis. Nat Med 2002;8:403-409

8. Caplice NM, Bunch TJ, Stalboerger PG, Wang S, Simper D, Miller DV, Russell SJ, Litzow MR, Edwards WD. Smooth muscle cells in human coronary atherosclerosis can originate from cells administered at marrow transplantation. Proc Natl Acad Sci U S A 2003;100:4754-4759

9. Bentzon JF, Weile C, Sondergaard CS, Hindkjaer J, Kassem M, Falk E. Smooth muscle cells in atherosclerosis originate from the local vessel wall and not circulating progenitor cells in ApoE knockout mice. Arterioscler Thromb Vasc Biol 2006;26:2696-2702

10. Bentzon JF, Sondergaard CS, Kassem M, Falk E. Smooth muscle cells healing atherosclerotic plaque disruptions are of local, not blood, origin in apolipoprotein E knockout mice. Circulation 2007;116:2053-2061

11. Torsney E, Mandal K, Halliday A, Jahangiri M, Xu Q. Characterisation of progenitor cells in human atherosclerotic vessels. Atherosclerosis 2007;191:259-264

12. Orlandi A, Di Lascio A, Francesconi A, Scioli MG, Arcuri G, Ferlosio A, Spagnoli LG. Stem cell marker expression and proliferation and apoptosis of vascular smooth muscle cells. Cell Cycle 2008;7:3889-3897

13. Gabbiani G, Kocher O, Bloom WS, Vandekerckhove J, Weber K. Actin expression in smooth muscle cells of rat aortic intimal thickening, human atheromatous plaque, and cultured rat aortic media. J Clin Invest 1984;73:148-152

14. Orlandi A, Ehrlich HP, Ropraz P, Spagnoli LG, Gabbiani G. Rat aortic smooth muscle cells isolated from different layers and at different times after endothelial denudation show distinct biological features in vitro. Arterioscler Thromb 1994;14:982-989

15. Bochaton-Piallat ML, Ropraz P, Gabbiani F, Gabbiani G. Phenotypic heterogeneity of rat arterial smooth muscle cell clones. Implications for the development of experimental intimal thickening. Arterioscler Thromb Vasc Biol 1996;16: $815-820$

16. Hao H, Ropraz P, Verin V, Camenzind E, Geinoz A, Pepper MS, Gabbiani G, Bochaton-Piallat ML. Heterogeneity of smooth muscle cell populations cultured from pig coronary artery. Arterioscler Thromb Vasc Biol 2002;22:1093-1099

17. Li S, Sims S, Jiao Y, Chow LH, Pickering JG. Evidence from a novel human cell clone that adult vascular smooth muscle cells can convert reversibly between noncontractile and contractile phenotypes. Circ Res 1999;85:338-348

18. Orlandi A, Ferlosio A, Gabbiani G, Spagnoli LG, Ehrlich $\mathrm{PH}$. Phenotypic heterogeneity influences the behavior of rat aortic smooth muscle cells in collagen lattice. Exp Cell Res 2005;311:317-327

19. Orlandi A, Ropraz P, Gabbiani G. Proliferative activity and alpha-smooth muscle actin expression in cultured rat aortic smooth muscle cells are differently modulated by transforming growth factor-beta 1 and heparin. Exp Cell Res 1994;214:528-536

20. Orlandi A, Francesconi A, Cocchia D, Corsini A, Spagnoli LG. Phenotypic heterogeneity influences apoptotic susceptibility to retinoic acid and cis-platinum of rat arterial smooth muscle cells in vitro: Implications for the evolution of experimental intimal thickening. Arterioscler Thromb Vasc Biol 2001;21:1118-1123

21. Orlandi A, Francesconi A, Marcellini M, Di Lascio A, Spagnoli LG. Propionyl-L-carnitine reduces proliferation and potentiates Bax-related apoptosis of aortic intimal smooth muscle cells by modulating nuclear factor-kappaB activity. J Biol Chem 2007;282:4932-4942

22. Orlandi A, Ferlosio A, Arcuri G, Scioli MG, De Falco S, Spagnoli LG. Flt-1 expression influences apoptotic susceptibility of vascular smooth muscle cells through the NF-kappaB/ IAP-1 pathway. Cardiovasc Res 2010;85:214-223

23. Gittenberger-de Groot AC, DeRuiter MC, Bergwerff $M$, Poelmann RE. Smooth muscle cell origin and its relation to heterogeneity in development and disease. Arterioscler Thromb Vasc Biol 1999;19:1589-1594

24. Topouzis S, Majesky MW. Smooth muscle lineage diversity in the chick embryo. Two types of aortic smooth muscle cell differ in growth and receptor-mediated transcriptional responses to transforming growth factor-beta. Dev Biol 1996;178:430-445

25. Suzuki S, Narita Y, Yamawaki A, Murase Y, Satake M, Mutsuga M, Okamoto H, Kagami H, Ueda M, Ueda Y. Effects of extracellular matrix on differentiation of human bone marrow-derived mesenchymal stem cells into smooth muscle cell lineage: utility for cardiovascular tissue engineering. Cells Tissues Organs 2010;191:269-280

26. Simper D, Stalboerger PG, Panetta CJ, Wang S, Caplice NM. Smooth muscle progenitor cells in human blood. Circulation 2002;106:1199-1204

27. Jiang Y, Jahagirdar BN, Reinhardt RL, Schwartz RE, Keene CD, Ortiz-Gonzalez XR, Reyes M, Lenvik T, Lund T, Blackstad M, Du J, Aldrich S, Lisberg A, Low WC, Largaespada DA, Verfaillie CM. Pluripotency of mesenchymal stem cells derived from adult marrow. Nature 2002;418:41-49

28. Sainz J, Al Haj Zen A, Caligiuri G, Demerens C, Urbain D, Lemitre M, Lafont A. Isolation of "side population" progenitor cells from healthy arteries of adult mice. Arterioscler Thromb Vasc Biol 2006;26:281-286

29. Jackson KA, Mi T, Goodell MA. Hematopoietic potential of stem cells isolated from murine skeletal muscle. Proc Natl Acad Sci U S A 1999;96:14482-14486

30. Tintut Y, Alfonso Z, Saini T, Radcliff K, Watson K, Boström K, Demer LL. Multilineage potential of cells from the artery wall. Circulation 2003;108:2505-2510 
31. Hu Y, Zhang Z, Torsney E, Afzal AR, Davison F, Metzler $\mathrm{B}, \mathrm{Xu} \mathrm{Q}$. Abundant progenitor cells in the adventitia contribute to atherosclerosis of vein grafts in ApoE-deficient mice. J Clin Invest 2004;113:1258-1265

32. Howson KM, Aplin AC, Gelati M, Alessandri G, Parati EA, Nicosia RF. The postnatal rat aorta contains pericyte progenitor cells that form spheroidal colonies in suspension culture. Am J Physiol Cell Physiol 2005;289:C1396-C13407

33. Hibbert B, Chen YX, O'Brien ER. c-kit-immunopositive vascular progenitor cells populate human coronary in-stent restenosis but not primary atherosclerotic lesions. Am J Physiol Heart Circ Physiol 2004;287:H518-H524

34. Spagnoli LG, Orlandi A, Santeusanio G. Foam cells of the rabbit atherosclerotic plaque arrested in metaphase by colchicine show a macrophage phenotype. Atherosclerosis 1991;88:87-92

35. Spagnoli LG, Orlandi A, Marino B, Mauriello A, De Angelis C, Ramacci MT. Propionyl-L-carnitine prevents the progression of atherosclerotic lesions in aged hyperlipemic rabbits. Atherosclerosis 1995;114:29-44

36. Morrow D, Cullen JP, Liu W, Guha S, Sweeney C, Birney YA, Collins N, Walls D, Redmond EM, Cahill PA. Sonic Hedgehog induces Notch target gene expression in vascular smooth muscle cells via VEGF-A. Arterioscler Thromb Vasc Biol 2009;29:1112-1118

37. Shi Y, Pieniek M, Fard A, O'Brien J, Mannion JD, Zalewski A. Adventitial remodeling after coronary arterial injury. Circulation 1996;93:340-348

38. Torsney E, Hu Y, Xu Q. Adventitial progenitor cells contribute to arteriosclerosis. Trends Cardiovasc Med 2005;15:64-68

39. Hu Y, Zhang Z, Torsney E, Afzal AR, Davison F, Metzler $\mathrm{B}, \mathrm{Xu} \mathrm{Q}$. Abundant progenitor cells in the adventitia contribute to atherosclerosis of vein grafts in ApoE-deficient mice. J Clin Invest 2004;113:1258-1265

40. Gimble JM, Katz AJ, Bunnell BA. Adipose-derived stem cells for regenerative medicine. Circ Res 2007;100:1249-1260

41. Orlandi A, Francesconi A, Marcellini M, Ferlosio A, Spagnoli LG. Role of ageing and coronary atherosclerosis in the development of cardiac fibrosis in the rabbit. Cardiovasc Res 2004;64:544-552

42. Cervelli V, Gentile P, Scioli MG, Grimaldi M, Casciani CU, Spagnoli LG, Orlandi A. Application of platelet-rich plasma in plastic surgery: clinical and in vitro evaluation. Tissue Eng Part C Methods 2009;15:625-634

43. Gentile P, Orlandi A, Scioli MG, Di Pasquali C, Bocchini I, Curcio CB, Floris M, Fiaschetti V, Floris R, Cervell V. A comparative translational study: the combined use of enhanced stromal vascular fraction and platelet-rich plasma improves fat grafting maintenance in breast reconstruction. Stem Cells Transl Med 2012;1:341-351

44. Cervelli V, Scioli MG, Gentile P, Doldo E, Bonanno E, Spagnoli LG, Orlandi A. Platelet-rich plasma greatly potentiates insulin-induced adipogenic differentiation of human adipose-derived stem cells through a serine/threonine kinase Akt-dependent mechanism and promotes clinical fat graft maintenance. Stem Cells Transl Med 2012;1:206-220
45. Scioli MG, Cervelli V, Arcuri G, Gentile P, Doldo E, Bielli A, Bonanno E, Orlandi A. High insulin-induced down-regulation of Erk-1/IGF-1R/FGFR-1 signaling is required for oxidative stress-mediated apoptosis of adipose-derived stem cells. J Cell Physiol 2014;229:2077-2087

46. Scioli MG, Bielli A, Gentile P, Mazzaglia D, Cervelli V, Orlandi A. The biomolecular basis of adipogenic differentiation of adipose-derived stem cells. Int J Mol Sci 2014;15:6517-6526

47. Cervelli V, Gentile P, De Angelis B, Calabrese C, Di Stefani A, Scioli MG, Curcio BC, Felici M, Orlandi A. Application of enhanced stromal vascular fraction and fat grafting mixed with PRP in post-traumatic lower extremity ulcers. Stem Cell Res 2011;6:103-111

48. Gentile P, Orlandi A, Scioli MG, Di Pasquali C, Bocchini I, Cervelli V. Concise review: adipose-derived stromal vascular fraction cells and platelet-rich plasma: basic and clinical implications for tissue engineering therapies in regenerative surgery. Stem Cells Transl Med 2012;1:230-236

49. Cervelli V, Garcovich S, Bielli A, Cervelli G, Curcio BC, Scioli MG, Orlandi A, Gentile P. The effect of autologous activated platelet rich plasma (AA-PRP) injection on pattern hair loss: clinical and histomorphometric evaluation. Biomed Res Int 2014;2014:760709

50. Cervelli V, Bocchini I, Di Pasquali C, De Angelis B, Cervelli G, Curcio CB, Orlandi A, Scioli MG, Tati E, Delogu P, Gentile P. P.R.L. platelet rich lipotransfert: our experience and current state of art in the combined use of fat and PRP. Biomed Res Int 2013;2013:434191

51. Bielli A, Scioli MG, Gentile P, Agostinelli S, Tarquini C, Cervelli V, Orlandi A. Adult adipose-derived stem cells and breast cancer: a controversial relationship. Springerplus 2014;3:345

52. De Angelis B, Gentile P, Orlandi F, Bocchini I, Di Pasquali C, Agovino A, Gizzi C, Patrizi F, Scioli MG, Orlandi A, Cervelli V. Limb Rescue: A New Autologous-Peripheral Blood Mononuclear Cells Technology in Critical Limb Ischemia and Chronic Ulcers. Tissue Eng Part C Methods 2015 [Epub ahead of print]

53. Koh YJ, Kang S, Lee HJ, Choi TS, Lee HS, Cho CH, Koh GY. Bone marrow-derived circulating progenitor cells fail to transdifferentiate into adipocytes in adult adipose tissues in mice. J Clin Invest 2007;117:3684-3695

54. Merfeld-Clauss S, Gollahalli N, March KL, Traktuev DO. Adipose tissue progenitor cells directly interact with endothelial cells to induce vascular network formation. Tissue Eng Part A 2010;16:2953-2966

55. Strassburg S, Nienhueser H, Stark GB, Finkenzeller G, Torio-Padron N. Human adipose-derived stem cells enhance the angiogenic potential of endothelial progenitor cells, but not of human umbilical vein endothelial cells. Tissue Eng Part A 2013;19:166-174

56. Crisan M, Yap S, Casteilla L, Chen CW, Corselli M, Park TS, Andriolo G, Sun B, Zheng B, Zhang L, Norotte C, Teng PN, Traas J, Schugar R, Deasy BM, Badylak S, Buhring HJ, Giacobino JP, Lazzari L, Huard J, Péault B. A peri- 
vascular origin for mesenchymal stem cells in multiple human organs. Cell Stem Cell 2008;3:301-313

57. Zoll J, Fontaine V, Gourdy P, Barateau V, Vilar J, Leroyer A, Lopes-Kam I, Mallat Z, Arnal JF, Henry P, Tobelem G, Tedgui A. Role of human smooth muscle cell progenitors in atherosclerotic plaque development and composition. Cardiovasc Res 2008;77:471-480

58. Orlandi A, Bennett M. Progenitor cell-derived smooth muscle cells in vascular disease. Biochem Pharmacol 2010;79: 1706-1713

59. Orlandi A, Mauriello A, De Angelis C, Ramacci MT, Spagnoli LG. Age-related differences in the distribution and occurrence of atherosclerotic aortic lesions in the hyperlipemic rabbit. Arch Gerontol Geriatr 1992;15 Suppl 1:295-302

60. Spagnoli LG, Orlandi A, Mauriello A, Santeusanio G, de Angelis C, Lucreziotti R, Ramacci MT. Aging and atherosclerosis in the rabbit. 1. Distribution, prevalence and morphology of atherosclerotic lesions. Atherosclerosis 1991;89: $11-24$

61. Orlandi A, Mauriello A, Marino B, Spagnoli LG. Age-related modifications of aorta and coronaries in the rabbit: a morphological and morphometrical assessment. Arch Gerontol Geriatr 1993;17:37-53

62. Spagnoli LG, Orlandi A, Mauriello A, De Angelis C, Ramacci MT. Age-dependent increase of rabbit aortic atherosclerosis. A morphometric approach. Pathol Res Pract 1992;188:637-642

63. Orlandi A, Francesconi A, Marcellini M, Ferlosio A, Spagnoli LG. Role of ageing and coronary atherosclerosis in the development of cardiac fibrosis in the rabbit. Cardiovasc Res 2004;64:544-552

64. Orlandi A, Francesconi A, Ferlosio A, Di Lascio A, Marcellini M, Pisano C, Spagnoli LG. Propionyl-L-carni- tine prevents age-related myocardial remodeling in the rabbit. J Cardiovasc Pharmacol 2007;50:168-175

65. Ferlosio A, Arcuri G, Doldo E, Scioli MG, De Falco S, Spagnoli LG, Orlandi A. Age-related increase of stem marker expression influences vascular smooth muscle cell properties. Atherosclerosis 2012;224:51-57

66. Campagnolo L, Costanza G, Francesconi A, Arcuri G, Moscatelli I, Orlandi A. Sortilin expression is essential for pro-nerve growth factor-induced apoptosis of rat vascular smooth muscle cells. PLoS One 2014;9:e84969

67. Tarallo V, Vesci L, Capasso O, Esposito MT, Riccioni T, Pastore L, Orlandi A, Pisano C, De Falco S. A placental growth factor variant unable to recognize vascular endothelial growth factor (VEGF) receptor-1 inhibits VEGF-dependent tumor angiogenesis via heterodimerization. Cancer Res 2010;70:1804-1813

68. Cassinelli G, Zuco V, Petrangolini G, De Cesare M, Tortoreto M, Lanzi C, Cominetti D, Zaffaroni N, Orlandi A, Passeri D, Meco D, Di Francesco AM, Riccardi R, Bucci F, Pisano C, Zunino F. The curative efficacy of namitecan (ST1968) in preclinical models of pediatric sarcoma is associated with antiangiogenic effects. Biochem Pharmacol 2012;84:163-171

69. Orlandi A, Bochaton-Piallat ML, Gabbiani G, Spagnoli LG. Aging, smooth muscle cells and vascular pathobiology: implications for atherosclerosis. Atherosclerosis 2006;188:221-230

70. Stasi MA, Scioli MG, Arcuri G, Mattera GG, Lombardo K, Marcellini M, Riccioni T, De Falco S, Pisano C, Spagnoli LG, Borsini F, Orlandi A. Propionyl-L-carnitine improves postischemic blood flow recovery and arteriogenetic revascularization and reduces endothelial NADPH-oxidase 4-mediated superoxide production. Arterioscler Thromb Vasc Biol 2010;30:426-435 